\title{
Nutritional support for head-injured patients (Review)
}

\author{
Perel P, Yanagawa T, Bunn F, Roberts IG, Wentz R
}

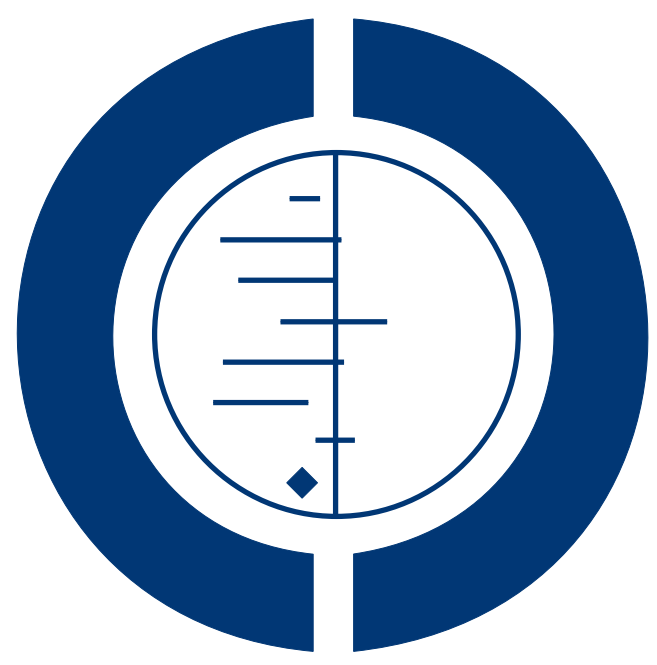

\section{THE COCHRANE COLLABORATION $^{\circledR}$}

This is a reprint of a Cochrane review, prepared and maintained by The Cochrane Collaboration and published in The Cochrane Library 2008, Issue 4

http://www.thecochranelibrary.com

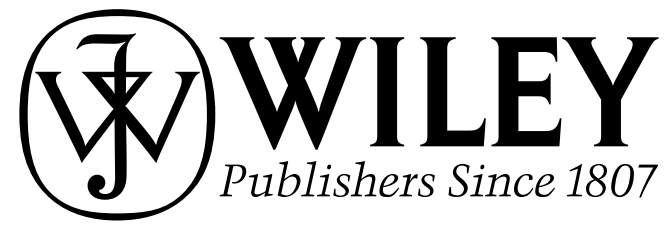

Nutritional support for head-injured patients (Review)

Copyright $\odot 2008$ The Cochrane Collaboration. Published by John Wiley \& Sons, Ltd. 
TABLE OF CONTENTS

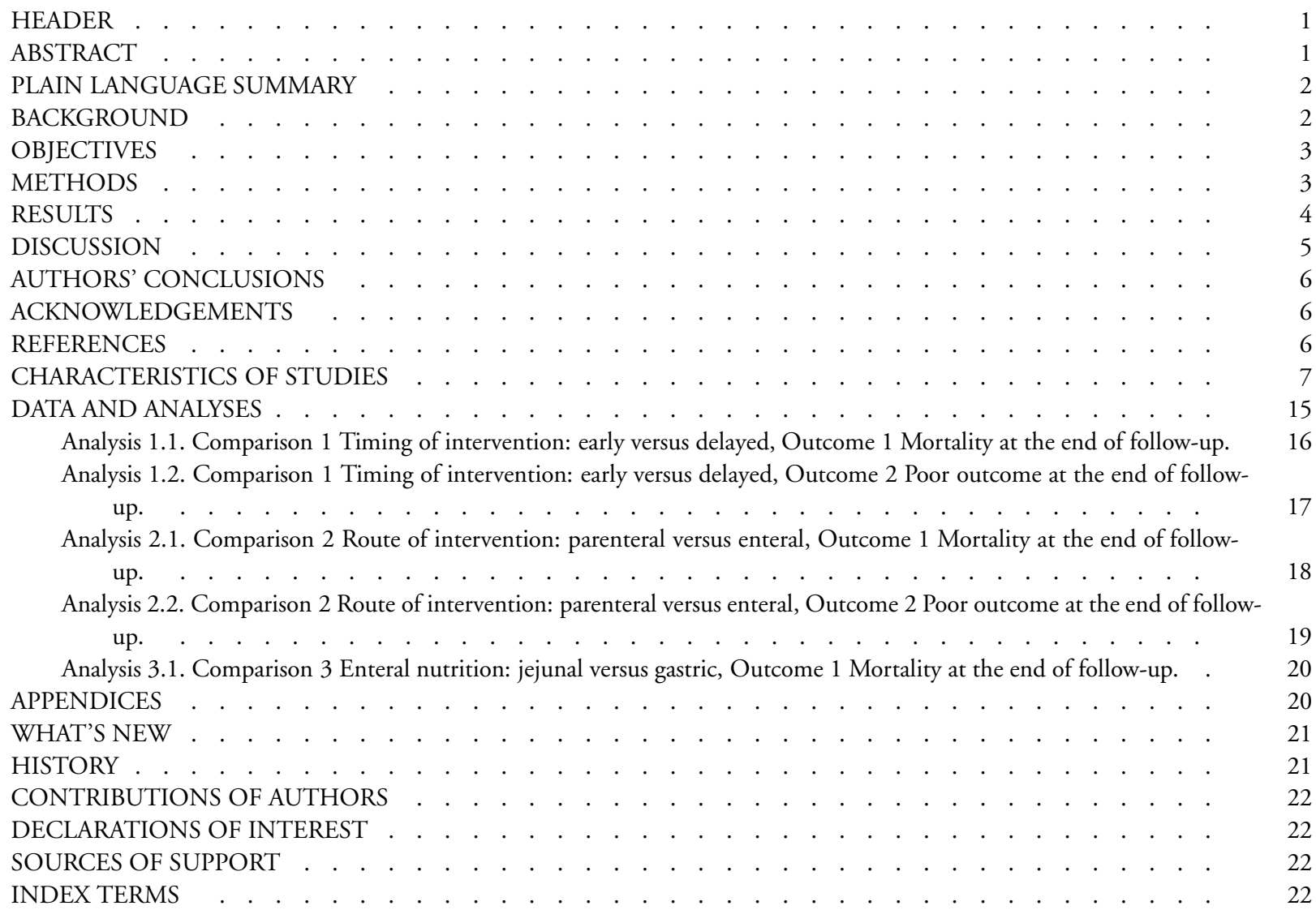




\title{
[Intervention Review]
}

\section{Nutritional support for head-injured patients}

\author{
Pablo Perel ${ }^{1}$, Toshihiko Yanagawa ${ }^{2}$, Frances Bunn ${ }^{3}$, Ian G Roberts ${ }^{1}$, Reinhard Wentz ${ }^{4}$ \\ ${ }^{1}$ Cochrane Injuries Group, London School of Hygiene \& Tropical Medicine, London, UK. ${ }^{2}$ School of Health and Nursing Science, \\ Wakayama Medical University, Wakayama, Japan. ${ }^{3}$ Centre for Research in Primary and Community Care, University of Hertfordshire, \\ Hatfield, UK. ${ }^{4}$ Imperial College School of Medicine, Chelsea and Westminister Hospital, London, UK
}

Contact address: Pablo Perel, Cochrane Injuries Group, London School of Hygiene \& Tropical Medicine, Keppel Street, London, WC1E 7HT, UK. pablo.perel@lshtm.ac.uk.

Editorial group: Cochrane Injuries Group.

Publication status and date: Edited (no change to conclusions), published in Issue 4, 2008.

Review content assessed as up-to-date: 1 August 2006.

Citation: Perel P, Yanagawa T, Bunn F, Roberts IG, Wentz R. Nutritional support for head-injured patients. Cochrane Database of Systematic Reviews 2006, Issue 4. Art. No.: CD001530. DOI: 10.1002/14651858.CD001530.pub2.

Copyright (C) 2008 The Cochrane Collaboration. Published by John Wiley \& Sons, Ltd.

\section{A B S T R A C T}

\section{Background}

Head injury increases the body's metabolic responses, and therefore nutritional demands. Provision of an adequate supply of nutrients is associated with improved outcome. The best route for administering nutrition (parenterally (TPN) or enterally (EN)), and the best timing of administration (for example, early versus late) of nutrients needs to be established.

\section{Objectives}

To quantify the effect on mortality and morbidity of alternative strategies of providing nutritional support following head injury.

\section{Search methods}

Trials were identified by computerised searches of the Cochrane Injuries Group specialised register, Cochrane Central Register of Controlled Trials, MEDLINE, EMBASE, National Research Register, Web of Science and other electronic trials registers. Reference lists of trials and review articles were checked. The searches were last updated in July 2006.

\section{Selection criteria}

Randomised controlled trials of timing or route of nutritional support following acute traumatic brain injury.

\section{Data collection and analysis}

Two authors independently abstracted data and assessed trial quality. Information was collected on death, disability, and incidence of infection. If trial quality was unclear, or if there were missing outcome data, trialists were contacted in an attempt to get further information.

\section{Main results}

A total of 11 trials were included. Seven trials addressed the timing of support (early versus delayed), data on mortality were obtained for all seven trials (284 participants). The relative risk (RR) for death with early nutritional support was 0.67 (95\% CI 0.41 to 1.07 ). Data on disability were available for three trials. The RR for death or disability at the end of follow-up was 0.75 (95\% CI 0.50 to 1.11 ). Seven trials compared parenteral versus enteral nutrition. Because early support often involves parenteral nutrition, three of the trials are also included in the previous analyses. Five trials (207 participants) reported mortality. The RR for mortality at the end of followup period was 0.66 ( 0.41 to 1.07). Two trials provided data on death and disability. The $\mathrm{RR}$ was 0.69 ( $95 \% \mathrm{Cl} 0.40$ to 1.19 ). One trial compared gastric versus jejunal enteral nutrition, there were no deaths and the RR was not estimable. 


\section{Authors' conclusions}

This review suggests that early feeding may be associated with a trend towards better outcomes in terms of survival and disability. Further trials are required. These trials should report not only nutritional outcomes but also the effect on death and disability.

\section{PLAIN LANGUAGE SUMMARY}

\section{Does the timing and route of nutritional support have an effect on survival and disability in head-injured patients?}

After a moderate or severe head injury, patients use more energy as their body's metabolism is working at a greater rate. This increases the body's nutritional requirements which may lead to malnutrition and other complications.

Patients are often unable to meet the increased requirements by oral feeding alone, even if oral feeding is possible, therefore other methods are required. However, the method and timing of nutritional support can differ. Some can be started immediately following head injury but others may be delayed until the digestive system is found to be functioning.

Enteral nutrition is provided by inserting a feeding tube via the nose or mouth, into the stomach or small intestine. The feeding tube delivers a liquid formula containing the required nutrients. Total parenteral nutrition (TPN) provides an alternative to conventional enteral feeding. Parenteral nutrition means feeding someone via their blood stream (intravenously). Total parenteral nutrition (TPN) means that a patient is only fed intravenously. This method may carry risks of infectious complications.

It is unclear whether the timing and route of the administration of nutrition has an effect on mortality and morbidity of head-injured patients. The authors of this a systematic review searched for all high quality trials to determine the best timing (early or delayed), and route (enteral or parental) of nutritional support following head injury.

The authors identified 11 eligible trials that investigated the timing and route of nutritional support in head-injured patients. These trials included a total of 534 patients. However, of the many of the trials had methodological weaknesses.

The authors found that early feeding may be associated with fewer infections and a trend towards better outcomes in terms of survival and disability. However, the trials were small so any improvements detected were on a small scale. Also the focus of many of the trials was on nutritional outcomes, and many did not report the effect on death and disability. The authors were unable to obtain data for death and disability for all of the included trials so they feel there may be a possibility of bias. Further trials of nutritional support following head injury are required. These trials should report death and disability as well nutritional outcomes. They should also be large enough to detect clinically important treatment effects.

\section{B A C K G R O U N D}

Patients with moderate and severe head injury demonstrate hypermetabolism, increased energy expenditure, and increased protein loss. Several reports demonstrate that following head injury energy requirements increase substantially (Deutsman 1986; Phillips 1988; Weekes 1996). Nitrogen excretion increases significantly for up to four weeks leading to increased nitrogen requirements (Clifton 1984). It has been argued that nutritional support can prevent the loss of immune competence, and decrease morbidity, mortality, and the length of hospital stay associated with head injury (Young 1987).

Nutritional support for acutely head-injured patients is sometimes delayed until gastrointestinal function has returned to normal in the post injury period (Ott 1989; Norton 1987; Rapp 1983). In particular, if enteral feeding is provided by a nasogastric tube, feeding is often delayed until bowel sounds are heard. Total parenteral nutrition (TPN) provides an alternative to conventional enteral feeding particularly in the acute post head injury period. However, the advantages of TPN may be offset by the occurrence of infectious complications such as septicaemia.

Early enteral nutrition may prevent malnutrition, intestinal mucosal atrophy and also preserve normal gut flora (Maynard 1991). Early enteral feeding has also been shown to reduce septic complications (Moore 1991). Jejunal feeding has been used to overcome poor gastric emptying. 
The relative effectiveness of the different nutritional strategies following head injury has been examined in a number of randomised controlled trials. To determine the best timing (early or delayed), and route (enteral or parenteral) of nutritional supplementation following head injury, a systematic review of randomised controlled trials was conducted.

\section{O B JE C T IVES}

To quantify the effect on mortality and morbidity of alternative strategies of providing nutritional support following head injury. Specifically, the effect of the timing and route of administration.

\section{METHODS}

\section{Criteria for considering studies for this review}

\section{Types of studies}

We sought to identify all randomised controlled trials of timing or route of nutritional support following acute traumatic brain injury.

\section{Types of participants}

People of all ages with acute traumatic brain injury of any severity. Patients with multiple injuries were included if the injuries included head injury.

\section{Types of interventions}

Randomised controlled trials comparing:

1. Early versus delayed nutritional support;

2. Parenteral versus enteral nutritional support;

3. Gastric versus jejunal enteral nutrition;

Mixed nutrition (enteral plus parenteral) was regarded as enteral if the enteral calories exceeded $50 \%$ of calorie intake.

\section{Types of outcome measures}

- All-cause mortality at the end of follow-up.

- Death and disability at the end of follow-up. Disability was assessed using the Glasgow Outcome Scale (Jennett 1975) which includes the following categories: death, persistent vegetative state, severely disabled, moderately disabled and good recovery. For the purpose of this review the scale was dichotomised with death, persistent vegetative state and severe disability denoting a poor outcome, and moderate disability and good recovery denoting a good outcome.
- Length of hospital stay.

- The frequency of infections.

\section{Search methods for identification of studies}

The searches were last updated in July 2006.

\section{Electronic searches}

We searched the following electronic databases;

- Cochrane Injuries Group specialised register

- Cochrane Central Register of Controlled Trials (CENTRAL)

- MEDLINE

- EMBASE

- Web of Science (including Science Citation Index)

- CAB abstracts

- CINAHL

- National Research Register

- ZETOC

The search strategy can be found in Appendix 1.

\section{Searching other resources}

We also checked the reference lists of all identified trials and review articles for relevant trials.

\section{Data collection and analysis}

\section{Selection of studies}

One author went through the search results and selected those papers that met the inclusion criteria.

\section{Data extraction and management}

Two authors independently extracted the following information from each trial:

- strategy for allocation concealment;

- number of randomised patients;

- duration of follow-up;

- number lost to follow-up.

The major outcome data sought were numbers of deaths and numbers of people disabled at the end of the study period. We also extracted data on the incidence of infections. 


\section{Assessment of risk of bias in included studies}

Since there is evidence that the quality of allocation concealment particularly affects the results of studies (Schulz 1995), two authors scored this quality on the scale used by Schulz (Schulz 1995) as shown below, assigning $\mathrm{C}$ to poorest quality and $\mathrm{A}$ to best quality: $\mathrm{C}=$ trials in which concealment was inadequate (such as alternation or reference to case record numbers or to dates of birth) $\mathrm{B}=$ trials in which the authors either did not report an allocation concealment approach at all or reported an approach that did not fall into category $\mathrm{A}$ or $\mathrm{C}$.

$\mathrm{A}=$ trials deemed to have taken adequate measures to conceal allocation (i.e. central randomisation; numbered or coded bottles or containers; drugs prepared by the pharmacy; serially numbered, opaque, sealed envelopes; or other description that contained elements convincing of concealment).

Where the method used to conceal allocation was not clearly reported, the authors were contacted, if possible, for clarification. We then compared the scores allocated and resolved differences by discussion.

\section{Data synthesis}

Relative risks and $95 \%$ confidence intervals for mortality were calculated for each trial. Heterogeneity between trials was tested using a Chi-squared test, where P less than or equal to 0.05 was taken to indicate significant heterogeneity. As long as statistical heterogeneity did not exist, for dichotomous data, relative risk and $95 \%$ confidence intervals were calculated using a fixed effects model. A funnel plot to detect publication bias was not attempted as there were too few trials to detect asymmetry.

\section{R E S U L T S}

\section{Description of studies}

See: Characteristics of included studies; Characteristics of excluded studies.

We identified 11 randomised controlled trials that looked at the timing and route of support in head-injured patients. These trials include a total of 534 patients. Seven trials looked at timing of the nutritional intervention (284 participants), and seven trials looked at the route of nutritional support (222 participants). Three of the trials (Hadley 1986, Rapp 1983, and Young 1987) are in both comparisons as they address early versus late, and parenteral versus enteral nutrition.

The timing of the nutritional intervention (early versus late) was looked at in the following trials:

Grahm 1989 (early jejunal feeding versus gastric feeding when bowel sounds returned)
Hadley 1986 (Early total parenteral nutrition (TPN) versus delayed nasogastric (NG) enteral feeding)

Minard 2000 (Early enteral feeding versus late enteral feeding) Rapp 1983 (Early TPN versus traditional enteral nutrition (EN)) Sacks 1995 (Early TPN versus delayed TPN)

Taylor 1999 (Standard EN versus enhanced EN). This study was included in the early versus late comparison as it was felt that the comparison of standard EN versus enhanced EN meant in effect that the patients in the enhanced EN group were getting more enteral feed sooner than those in the standard EN group.

Young 1987 (Early TPN versus delayed EN). The Young study was reported in two papers, one with the first 58 patients and the second with the total 96 patients. However, deaths were only reported in the first paper with 58 patients and so this report was used for the purpose of the meta-analysis.

The route of the nutritional intervention was looked at in the following trials:

Borzotta 1994 (TPN versus jejunal EN)

Chiarelli 1996 (All patients received TPN then one group weaned to total EN and one group had mixed TPN and EN. Because the enteral calories did not exceed $50 \%$ of the total intake this group was classified as TPN)

Hadley 1986 (TPN versus NG EN)

Nataloni 1999 (EN versus TPN)

Rapp 1983 (TPN versus EN)

Suchner 1996 (TPN versus EN - both started at the same time) Young 1987 (TPN versus EN)

For a more detailed description of individual studies please see the 'Characteristics of Included Studies' table.

\section{Risk of bias in included studies}

Of the 11 eligible randomised controlled trials, the quality of allocation concealment was unclear in seven and inadequate in four. Borzotta 1994

Allocation concealment $(\mathrm{AC})=\mathrm{B}$

The study was a prospective, randomised, non blinded clinical comparison. Randomisation was done using a computer-generated random number table but method of allocation concealment is not described. Two patients in the TPN group and eight in the EN group were lost to follow-up.

Chiarelli 1996

$\mathrm{AC}=\mathrm{B}$

The study was a randomised controlled trial. The methods of randomisation and allocation concealment are not described.

Grahm 1989

$\mathrm{AC}=\mathrm{C}$

Patients were randomised according to their day of admission. Patients admitted on odd days were entered into the control group and those admitted on even days into the experimental group. To balance the size of the group, four patients admitted on odd days were placed into the experimental group. No loss to follow-up. 
Hadley 1986

$\mathrm{AC}=\mathrm{C}$

The study was described as a randomised controlled trial but allocation was based on their date of admission. No loss to followup.

Minard 2000

$\mathrm{AC}=\mathrm{B}$

The study is reported as randomised but the method of randomisation and allocation concealment are not described. Patients were followed up until discharge.

Nataloni 1999

$\mathrm{AC}=\mathrm{B}$

The study is reported as randomised but the method of randomisation and allocation concealment are not described.

Rapp 1983

$\mathrm{AC}=\mathrm{B}$

The study is reported as randomised but the method of randomisation and allocation concealment are not described. All patients followed up until discharge, one patient in the TPN group was lost to follow-up at one year.

Sacks 1995

$\mathrm{AC}=\mathrm{C}$

The study was a randomised, double-blind trial. Patients were randomised using a table of random numbers read by someone entering the patient into the trial (open list). Four patients in each group did not complete the minimum of 14 days in the study and were removed. Of these two in the early $\mathrm{PN}$ group and three in the delayed PN group died.

Suchner 1996

$\mathrm{AC}=\mathrm{B}$

The study is a prospective, open-label trial with a randomisation schedule established prior to the start of the trial. Fifteen patients were lost to follow-up. Seven patients were excluded from the final analysis.

Taylor 1999

$\mathrm{AC}=\mathrm{C}$

This is a randomised controlled trial. Patients were randomised using a balanced six block sequence generated from a random number table in a 1:1 ratio, to the control or intervention group (Open list).

Young 1987

$\mathrm{AC}=\mathrm{B}$

The study is reported as randomised but the method of randomisation and allocation concealment are unknown. Fifty-eight patients were originally enrolled into the study. Patients who were brain dead within four days of entering the study or whose families decided to withdraw them from the study within five days of enrolment were excluded from analysis. Seven patients were excluded for the above reasons, leaving 51 patients for analysis. Of those five were brain dead within four days (four TPN group, one EN group).

\section{Effects of interventions}

\section{The timing of support: early versus delayed}

Of the seven trials addressing the timing of support, data on mortality were obtained for all seven trials (284 participants). The relative risk (RR) for death with early nutritional support was 0.67 (95\% CI 0.41 to 1.07 ).

Data on disability were available for three of the seven trials ( Hadley 1986; Rapp 1983; Taylor 1999). The RR for poor outcome at the end of follow-up was 0.75 (95\% CI 0.50 to 1.11 ).

One study (Taylor 1999) reported median number of days of hospital stay and one study (Grahm 1989) reported length of stay in the ICU. The study by Minard 2000 reported median length of stay in ICU and in hospital.

\section{The route of feeding: parenteral versus enteral}

Seven trials were found which compared parenteral versus enteral nutrition. Because early support often involves parenteral nutrition, three of the seven trials are also included in the previous analyses.

Five of the trials reported mortality (Borzotta 1994; Chiarelli 1996; Hadley 1986; Rapp 1983; Young 1987) (207 participants). The RR for mortality at the end of follow-up period was 0.66 (95\% CI 0.41 to 1.07). The RR for poor outcome was 0.69 (95\% Cl 0.40 to 1.19) from two of the five trials (Hadley 1986; Rapp 1983). Two trials (Borzotta 1994; Chiarelli 1996) reported the length of hospital stay.

\section{Enteral nutrition: jejunal versus gastric}

There was one trial in this category. There were no deaths in this trial and the relative risk is not estimable.

The data on incidence of infection was presented in a number of different ways in different trials and we were therefore unable to combine it in a meta-analysis. These data are presented in the 'Other Data' table.

\section{DISCUSSION}

This systematic review summarises the evidence from randomised controlled trials of nutritional support following head injury.

Timing of nutritional support is strongly influenced by the type of feeding used. Parenteral nutritional was usually started between 24 and 72 hours of the injury, but mostly within 48 hours of the injury. In the case of enteral (nasogastric tube) feeding, nutritional support typically started much later when bowel sounds could be heard, usually between three and five days of injury. Jejunal enteral feeding, however, could be started earlier despite poor gastric 
emptying. This review addressed the timing and route of nutritional support. There was a trend towards improved survival and reduced disability with early support but the trials were small and the precision of the point estimates was low.

The pooled results from trials comparing parenteral and enteral nutrition suggested a trend towards better outcomes with parenteral nutrition, although again, the precision of the point estimates for mortality was low. In this comparison the trials by Hadley 1986, Rapp 1983, and Young 1987 used nasogastric tube feeding for the enteral arm of the trial, in which case the observed effects may be explained by the timing rather than the route of feeding. Two trials reported the effect of route of feeding on the incidence of infection of any type, but both trials showed a trend towards more infection with TPN than with EN. If valid, this might reflect catheter related infection with TPN. Three trials reported the effect of route of feeding on the occurrence of pneumonia, and there was a trend towards a reduction in incidence of pneumonia in the TPN group.

The focus of many of the trials included in this review was on nutritional outcomes, and many failed to report the effect of the alternative feeding strategies on death and disability. We wrote to all of the authors of the included trials in an attempt to obtain any unpublished outcome data, but many of the trialists could not be contacted. Because we were unable to obtain mortality and disability data for all of the included trials we cannot exclude the possibility of bias due to the selective publication of trial outcomes showing stronger treatment effects. Also the length of follow-up varied from two weeks to 12 months in those trials that did look at disability.

It would appear from this review that there have been few trials into nutritional support following head injury, which makes it hard for the clinician to make an evidence-based decision about nutritional support in head-injured patients. Overall the quality of the trials was poor. All of the trials had either inadequate or unclear allocation concealment and most had not attempted to do an intention to treat analysis. Indeed in some of the studies they admitted excluding from the final analysis patients who had died.

\section{A U THORS' CONCLUSIONS}

\section{Implications for practice}

The results of this review suggest that early feeding may be associated with fewer infections and a trend towards better outcomes in terms of survival and disability. However, the trials were small and consequently the precision of the point estimates was low.

\section{Implications for research}

Further trials of nutritional support following head injury are required. These trials should report not only nutritional outcomes but also outcomes such as death, disability, infectious complications and ICU and hospital length of stay. Trials should be large enough to detect modest but nevertheless clinically important treatment effects.

\section{ACKNOWLEDGEMENTS}

Imperial Gift Foundation Boshi-Aiiku-kai (Aiiku Association for Maternal Health and Welfare). Thanks to Phil Alderson for dealing with the editorial process for this review.

\section{REFER E N C E S}

\section{References to studies included in this review}

\section{Borzotta 1994 \{published data only\}}

Borzotta AP, Pennings J, Papasadero B, Paxton J, Mardesic $S$, Borzotta R, et al.Enteral versus parenteral nutrition after severe closed head injury. Journal of Trauma 1994;37(3): 459-68. [MEDLINE: 1994365870]

\section{Chiarelli 1996 \{published data only\}}

Chiarelli AG, Ferrarello S, Piccioli A, Abate A, Chini G, Berioli $\mathrm{MB}$, et al.Total enteral nutrition versus mixed enteral and parenteral nutrition in patients at an intensive care unit. Minerva Anestesiologica 1996;62(1-2):1-7. [MEDLINE: 1996300951]

Grahm 1989 \{published data only\} Grahm TW, Zadrozny DB, Harrington T. The benefits of early jejunal hyperalimentation in the head-injured patient. Neurosurgery 1989;25(5):729-35. [MEDLINE: 1990066993]

Hadley 1986 \{published data only\}

Hadley MN, Grahm TW, Harrington T, Schiller WR, McDermott MK, Posillico DB. Nutritional support and neurotrauma: a critical review of early nutrition in fortyfive acute head injury patients. Neurosurgery 1986;19(3): 367-73. [MEDLINE: 1987015191]

Minard 2000 \{published data only\} Minard G, Kudsk K, Melton S, Patton JH, Tolley EA. Early versus delayed feeding with an immune-enhancing diet in patients with severe head injuries. Journal of Parenteral and Enteral Nutrition 2000;24(3):145-9.

Nataloni 1999 \{published data only\} Nataloni S, Gentili P, Marini B, Guidi A, Marconi P, Busco $\mathrm{F}$, et al.Nutritional assessment in head injured patients 
through the study of rapid turnover visceral proteins. Clinical nutrition 1999;18(4):247-51.

Rapp 1983 \{published data only\}

Rapp RP, Young DB, Twyman D, Bivins BA, Haack D, Tibbs PA, et al.The favorable effect of early parenteral feeding on survival in head-injured patients. Journal of Neurosurgery 1983;58(6):906-12.

Sacks 1995 \{published data only\} Sacks GS, Brown RO, Teague D, Dickerson RN, Tolley EA, Kudsk KA. Early nutrition support modifies immune function in patients sustaining severe head injury. Journal of Parenteral and Enteral Nutrition 1995;19(5):387-92.

Suchner 1996 \{published data only\}

Suchner U, Senftleben U, Eckart T, Scholz M, Beck K, Murr R, et al.Enteral versus parenteral nutrition: Effect on gastrointestinal function and metabolism. Nutrition 1996; 12:13-22.

\section{Taylor 1999 \{published data only\}}

Taylor SJ, Fettes SB. Enhanced enteral nutrition in head injury: effect on the efficacy of nutritional delivery, nitrogen balance, gastric residuals and risk of pneumonia. Journal of Human Nutrition and Dietetics 1998;11(5):391-401.

* Taylor SJ, Fettes SB, Jewkes C, Nelson R. Prospective, randomized, controlled trial to determine the effect of early enhanced enteral nutrition on clinical outcome in mechanically ventilated patients suffering head injury. Critical Care Medicine 1999;27(11):2525-31.

Young 1987 \{published data only\}

Young B, Ott L, Haack D, Twyman D, Combs D, Oexmann $\mathrm{JB}$, et al.Effect of total parenteral nutrition upon intracranial pressure in severe head injury. Journal of Neurosurgery 1987; 67:76-80.

* Young B, Ott L, Twyman D, Norton J, Rapp R, Tibbs P, et al.The effect of nutritional support on outcome from severe head injury. Journal of Neurosurgery 1987;67(5):668-76.

\section{References to studies excluded from this review}

\section{Hausmann 1985 \{published data only\}}

Hausmann D, Mosebach KO, Caspari R, Rommelsheim K. Combined enteral-parenteral nutrition versus total parenteral nutrition in brain-injured patients. A comparative study. Intensive Care Medicine 1985;11(2): $80-4$.

\section{Additional references}

\section{Clifton 1984}

Clifton GL, Robertson CS, Grossman RG, Hodge S, Foltz $\mathrm{R}$, Garza C. The metabolic response to severe head injury. Journal of Neurosurgery 1984;60(4):687-96. [MEDLINE: 1984090046]

\section{Deutsman 1986}

Deutschman CS, Konstantinides FN, Raup S, Thienprasit P, Cerra FB. Physiological and metabolic response to isolated closed-head injury. Part 1: Basal metabolic state: correlations of metabolic and physiological parameters with fasting and stressed controls. Journal of Neurosurgery 1986; 64(1):89-98. [MEDLINE: 1986088665]

\section{Glanville 2006}

Glanville JM, Lefebvre C, Miles JN, Camosso-Stefinovic J. How to identify randomized controlled trials in MEDLINE: ten years on. Journal of the Medical Library Association 2006; 94((2)):130-6.

\section{Jennett 1975}

Jennett B, Bond M. Assessment of outcome after severe brain damage. A practical scale. Lancet 1975;1:480-4.

\section{Maynard 1991}

Maynard ND, Bihari DJ. Postoperative feeding. BMJ 1991; 303(6809):1007-8. [MEDLINE: 1991320073]

\section{Moore 1991}

Moore FA, Feliciano DV, Andrassy RJ, McArdle AH, Booth FV, Morgenstein-Wagner TB, et al.Early enteral feeding, compared with parenteral, reduces postoperative septic complications. The results of a meta-analysis. Annals of Surgery 1992;216(2):172-83.

Norton 1987

Norton JA, Ott LG, McClain C, Adams L, Dempsey RJ, Haack D, et al.Intolerance to enteral feeding in the braininjured patient. Journal of Neurosurgery 1988;68(1):62-6. [MEDLINE: 1988019134]

Ott 1989

Ott L, McClain C, Young B. Nutrition and severe brain injury. Nutrition 1989;5(2):75-9. [MEDLINE: 1989240017]

\section{Phillips 1988}

Phillips R, Ott L, Young B, Walsh J. Nutritional support and measured energy expenditure of the child and adolescent with head injury. Journal of Neurosurgery 1987;67(6): 846-51. [MEDLINE: 1988005529]

\section{Schulz 1995}

Schulz KF, Chalmers I, Hayes RJ, Altman DG. Empirical Evidence of Bias. Dimensions of methodological quality associated with estimates of treatment effects in controlled trials. JAMA 1995;273:408-12.

Weekes 1996

Weekes E, Elia M. Observations on the patterns of 24-hour energy expenditure changes in body composition and gastric emptying in head-injured patients receiving nasogastric tube feeding. Journal of Parenteral and Enteral Nutrition 1996; 20:31-7.

* Indicates the major publication for the study 
CHARACTERISTICS OF STUDIES

Characteristics of included studies [ordered by study ID]

Borzotta 1994

\begin{tabular}{ll}
\hline Methods & $\begin{array}{l}\text { Randomised controlled trial (computer-generated random number table) non-blinded. Allocation con- } \\
\text { cealment not mentioned }\end{array}$ \\
\hline Participants & $\begin{array}{l}59 \text { patients with head injury (including multiple injuries); } 18 \text { to } 60 \text { years, Glasgow Coma Scale scores } 8 \\
\text { or less persisting over } 24 \text { hours. } \\
\text { Patients with spinal cord injury, pre-existing metabolic disease, renal failure or inflammatory bowel disease, } \\
\text { were excluded }\end{array}$ \\
\hline Interventions & $\begin{array}{l}\text { 1) Parenteral nutrition (TPN) } \mathrm{n}=21 \\
\text { 2) Jejunal enteral nutrition }(\mathrm{EN}) \mathrm{n}=28\end{array}$ \\
\hline Outcomes & $\begin{array}{l}\text { Death } \\
\text { LHS } \\
\text { Infection } \\
\text { MREE } \\
\text { Nitrogen excretion }\end{array}$ \\
\hline Notes & $\begin{array}{l}\text { Patients were followed up until they took all nutrition orally or until discharge. Twenty-three patients } \\
\text { were enrolled into the TPN group and } 36 \text { into the ENT group; however 2 in the TPN group were lost } \\
\text { to follow-up and } 8 \text { in the EN group }\end{array}$ \\
\hline
\end{tabular}

\section{Risk of bias}

\begin{tabular}{l|ll}
\hline Item & Authors' judgement & Description \\
\hline Allocation concealment? & Unclear & B - Unclear \\
\hline
\end{tabular}

\section{Chiarelli 1996}

\begin{tabular}{l|l}
\hline Methods & Randomised controlled trial. Method of randomisation or allocation concealment is not described \\
\hline Participants & $\begin{array}{l}24 \text { patients requiring intensive care after major surgery or suffering from severe head injury or major } \\
\text { neurological impairment }\end{array}$ \\
\hline Interventions & $\begin{array}{l}\text { All patients initially received total parenteral nutrition. } \\
\text { After } 4 \text { days they were weaned to } \\
\text { 1) TEN }(\mathrm{n}=12)\end{array}$ \\
\hline 2) Mixed EN and TPN (n=12). In this group $50 \%$ of calories came from EN and $50 \%$ from TPN \\
\hline Outcomes & $\begin{array}{l}\text { Death } \\
\text { LHS } \\
\text { Bronchioaspiration } \\
\text { Nutritional parameters }\end{array}$ \\
\hline
\end{tabular}


Chiarelli 1996 (Continued)

\section{Diarrhoea}

\begin{tabular}{|c|c|c|}
\hline Notes & & \\
\hline \multicolumn{3}{|l|}{ Risk of bias } \\
\hline Item & Authors' judgement & Description \\
\hline Allocation concealment? & Unclear & B - Unclear \\
\hline
\end{tabular}

Grahm 1989

\begin{tabular}{ll}
\hline Methods & $\begin{array}{l}\text { Patients were randomised based on their date of admission. Patients admitted on odd days were entered } \\
\text { into the control group and those admitted on even days into the experimental group }\end{array}$ \\
\hline Participants & 32 patients with severe head injury and a GCS of 10 or less persisting for 6 hours \\
\hline Interventions & $\begin{array}{l}\text { 1) Early jejunal EN (under fluoroscopic, within } 36 \mathrm{hr} \text { ) } \mathrm{n}=17 \\
\text { 2) EN (gastric feedings initiated after day } 3 \text { or when gastric function returned) } \mathrm{n}=15\end{array}$ \\
\hline Outcomes & $\begin{array}{l}\text { Deaths } \\
\text { LHS } \\
\text { Infection } \\
\text { Nitrogen balance }\end{array}$ \\
\hline Notes & $\begin{array}{l}\text { Follow-up until discharge. No loss to follow-up. Four patients who should have been in the experimental } \\
\text { group were placed in the control group because they were unable to start early feeding. To balance the size } \\
\text { of the group four patients who should have been put in the control group were put into the experimental } \\
\text { group }\end{array}$ \\
\hline
\end{tabular}

\section{Risk of bias}

\begin{tabular}{lll}
\hline Item & Authors' judgement & Description \\
\hline Allocation concealment? & No & C - Inadequate \\
\hline
\end{tabular}

\section{Hadley 1986}

\begin{tabular}{l|l}
\hline Methods & Randomised controlled trial. Patients were randomised based on their date of admission \\
\hline Participants & 45 patients with isolated head injury GCS 10 or less at 6 hr. post injuries, age 16-61 \\
\hline Interventions & $\begin{array}{l}\text { Nutritional support within } 48 \text { hours as either: } \\
\text { 1) TPN (8.5\% amino acid, } 25 \% \text { glucose solution, } 10 \% \text { intralipid twice weekly) } \mathrm{n}=24 \\
\text { 2) EN (nasogastric, Isocal HCN) } \mathrm{n}=21\end{array}$
\end{tabular}


Hadley 1986 (Continued)

\begin{tabular}{|c|c|c|}
\hline Outcomes & \multicolumn{2}{|c|}{$\begin{array}{l}\text { Death } \\
\text { Disability (GCS } 8 \text { or less) } \\
\text { Infection (pneumonia and sepsis) }\end{array}$} \\
\hline Notes & \multicolumn{2}{|c|}{$\begin{array}{l}\text { Patients were followed up for } 14 \text { days or until their urinary nitrogen excretion fell below } 14 \mathrm{~g} \text { a day. No } \\
\text { loss to follow-up }\end{array}$} \\
\hline \multicolumn{3}{|l|}{ Risk of bias } \\
\hline Item & Authors' judgement & Description \\
\hline Allocation concealment? & No & C - Inadequate \\
\hline
\end{tabular}

\section{Minard 2000}

\begin{tabular}{|c|c|c|}
\hline Methods & \multicolumn{2}{|c|}{ Randomised controlled trial. No details given on method of randomisation or allocation concealment } \\
\hline Participants & \multicolumn{2}{|c|}{$\begin{array}{l}30 \text { patients with severe head injury as defined by a glasgow coma score greater than } 3 \text { and less than } 11 \\
\text { within } 6 \text { hours of injury }\end{array}$} \\
\hline Interventions & \multicolumn{2}{|c|}{$\begin{array}{l}\text { 1) Early feeding via nasogastric tube placed endoscopically, feeding within } 60 \text { hours of injury }(\mathrm{n}=12) \text {. } \\
\text { 2) Feeding initiated when gastroparesis resolved }(\mathrm{n}=15) \text {. } \\
\text { All patients received an immune-enhancing formula containing supplemental arginine, nucleic acids, fatty } \\
\text { acids and fiber }\end{array}$} \\
\hline Outcomes & \multicolumn{2}{|c|}{$\begin{array}{l}\text { Death } \\
\text { GCS scores } \\
\text { Number of days to a GCS of } 14 \\
\text { Length of hospital stay } \\
\text { Infections } \\
\text { Feeding complications }\end{array}$} \\
\hline Notes & \multicolumn{2}{|c|}{$\begin{array}{l}\text { Patients were followed daily for } 14 \text { days, after which only data on infections, length of stay and mortality } \\
\text { were recorded. } \\
3 \text { patients were dropped from the analysis, two in the early group because a nasoenteric tube could not } \\
\text { be passed, and one in the delayed group who died } 72 \text { hours after injury }\end{array}$} \\
\hline \multicolumn{3}{|l|}{ Risk of bias } \\
\hline Item & Authors' judgement & Description \\
\hline Allocation concealment? & Unclear & B - Unclear \\
\hline
\end{tabular}


Nataloni 1999

\begin{tabular}{|c|c|}
\hline Methods & Randomised controlled trial. No details given on method of randomisation or allocation concealment \\
\hline Participants & $\begin{array}{l}30 \text { patients with head injury who were expected to stay in the ICU for more than } 3 \text { days. Patients were } \\
\text { excluded if they had diabetes mellitus, renal or hepatic failure, pancreatitis, abdominal surgery or brain } \\
\text { death }\end{array}$ \\
\hline Interventions & $\begin{array}{l}\text { 1) Enteral } \\
\text { 2) Parenteral } \\
\text { In all patients feeding was initiated } 2 \text { days after ICU admission and continued until ICU discharge }\end{array}$ \\
\hline Outcomes & $\begin{array}{l}\text { Plasma prealbumin } \\
\text { Retinol binding protein }\end{array}$ \\
\hline Notes & No information given on deaths or disability. \\
\hline \multicolumn{2}{|l|}{ Risk of bias } \\
\hline Item & Authors' judgement \\
\hline Allocation concealment? & B - Unclear \\
\hline
\end{tabular}

Rapp 1983

\begin{tabular}{ll}
\hline Methods & Randomised controlled trial. No details given on method of randomisation or allocation concealment \\
\hline Participants & $\begin{array}{l}38 \text { head-injured patients. Patients with severe extracranial injuries that were expected to alter metabolic } \\
\text { demands or to delay use of standard enteral nutrition, such as abdominal organ injury, were excluded } \\
\text { from the study }\end{array}$ \\
\hline Interventions & $\begin{array}{l}\text { 1) Total parenteral nutrition (TPN); within 48hr, 42.5g/l AA, 25\% dextrose, 250-500 soybean oil (n= } \\
\text { 20) }\end{array}$ \\
\hline 2) Standard enteral nutrition (SEN); nasogastric, Vital ( a high nitrogen product) (n= 18)
\end{tabular}

\section{Risk of bias}

\begin{tabular}{l|l} 
Item & Authors' judgement
\end{tabular}


Rapp 1983 (Continued)

\begin{tabular}{lll}
\hline Allocation concealment? & Unclear & B - Unclear \\
\hline
\end{tabular}

\section{Sacks 1995}

\begin{tabular}{l|l}
\hline Methods & $\begin{array}{l}\text { Randomised controlled trial. Patients were randomised using a table of random numbers. The list of } \\
\text { random numbers was read by someone entering the patient into the trial (open list) }\end{array}$ \\
\hline Participants & $\begin{array}{l}9 \text { patients with severe closed head injury, } 18 \text { to } 65 \text { years, GCS } 3 \text { to } 12 \\
\text { Patients with hepatic dysfunction, hypertriglycemia, infection, or significant intra-abdominal injuries were } \\
\text { excluded }\end{array}$ \\
\hline Interventions & $\begin{array}{l}\text { 1) Early PN at day } 1 \text { (n = 4) } \\
\text { 2) Delayed PN at day } 5 \text { (n= 5) }\end{array}$ \\
\hline Outcomes & $\begin{array}{l}\text { Death } \\
\text { Immunological parameters } \\
\text { Disability } \\
\text { Infection }\end{array}$ \\
\hline Notes & $\begin{array}{l}17 \text { patients were enrolled in the study but } 8 \text { patients (four in each group) did not complete a minimum } \\
\text { of } 14 \text { days of the study and were removed from the study. Of these } 8 \text { patients } 3 \text { patients (early PN=2, } \\
\text { delayed PN=3) died before receiving } 7 \text { days of PN. } \\
\text { Information on allocation concealment and disability and infection rates were obtained on contact with } \\
\text { the author. Follow-up was for 30 days }\end{array}$ \\
\hline Allocation concealment? & $\begin{array}{l}\text { No } \\
\text { Authors judgement }\end{array}$ \\
\hline
\end{tabular}

Suchner 1996

\begin{tabular}{|c|c|}
\hline Methods & Prospective, open-label trial with a randomisation schedule established prior to the start of the trial \\
\hline Participants & $\begin{array}{l}34 \text { patients with traumatic head injury or spontaneous cerebral lesion undergoing an emergency cran- } \\
\text { iotomy (trauma 13, spontaneous cerebral lesion } 21 \text { ) with a GCS } 10 \text { or less (but } 2 \text { exceptions) } \\
\text { Patients with hepatic or renal failure, diabetes mellitus, hypermetabolic disease, or malnutrition were } \\
\text { excluded }\end{array}$ \\
\hline Interventions & $\begin{array}{l}\text { Initiated on the first postoperative day as either: } \\
\text { 1) TPN; glucose 10,20,40\%, amino acid 10\%, lipid 20\% (half MCT) }(n=17) \\
\text { 2) TEN; nasogastric, OSMOLITE ( } n=17)\end{array}$ \\
\hline Outcomes & $\begin{array}{l}\text { GCS } \\
\text { Haematology } \\
\text { Nutritional parameters }\end{array}$ \\
\hline
\end{tabular}


Suchner 1996 (Continued)

\begin{tabular}{|c|c|c|}
\hline Notes & \multicolumn{2}{|c|}{$\begin{array}{l}49 \text { patients were enrolled in the study, but only } 34 \text { completed it. Six patients (TEN 4, TPN 2) droppec } \\
\text { out of the study because of early recovery, extubation, and transfer to another ward. Four enterally anc } \\
\text { five parenterally fed patients were withdrawn from the study due to hemodynamic instability and septi } \\
\text { complications }\end{array}$} \\
\hline \multicolumn{3}{|l|}{ Risk of bias } \\
\hline Item & Authors' judgement & Description \\
\hline Allocation concealment? & Unclear & B - Unclear \\
\hline
\end{tabular}

\section{Taylor 1999}

Methods

Randomised controlled trial. Patients were randomised, using a balanced six block sequence generated from a random number table, in a 1:1 ratio, to the control or intervention group

82 patients with severe head injury necessitating mechanical ventilation, best GCS above 3, over 10 years old were included in the trial.

Patients with a gunshot head wound, presence of organ failure, potentially fatal disease pre-head injury, or moribund state immediately post-head injury were excluded

\begin{tabular}{ll}
\hline Interventions & 1) Enhanced EN (n=41) \\
2) Standard EN (n=41) \\
Enteral nutrition was started from day 1 in both groups of patients. In the intervention group (enhanced \\
EN) patients were started at the feed rate that would meet their full estimated requirements from day 1. \\
Control patients received EN via orogastric or nasogastric tubes and intervention patients received EN \\
via intestinal feeding (although where this was not possible they received gastric feeding) \\
\hline Outcomes & Death \\
LHS & Infection \\
& GCS \\
& Enteral feeding and drug cost \\
\hline
\end{tabular}

Neurological outcome was assessed at six and 12 months by a telephone interview with the patient's closest relative. There was a trend towards improved outcome at 3 months (61\% intervention vs $39 \%$ control), which disappeared by 6 months ( $68 \%$ intervention vs $61 \%$ control)

\section{Risk of bias}

\begin{tabular}{l|ll}
\hline Item & Authors' judgement & Description \\
\hline Allocation concealment? & No & C - Inadequate \\
\hline
\end{tabular}


Young 1987

\begin{tabular}{|c|c|c|}
\hline Methods & \multicolumn{2}{|c|}{$\begin{array}{l}\text { Randomised controlled trial. Method of randomisation not described. Allocation concealment not men- } \\
\text { tioned }\end{array}$} \\
\hline Participants & \multicolumn{2}{|c|}{ Fifty-one brain-injured patients with peak $24 \mathrm{hr}$, GCS of 4 to 10} \\
\hline Interventions & \multicolumn{2}{|c|}{$\begin{array}{l}\text { 1) TPN within } 48 \mathrm{hr}(\mathrm{n}=23) \\
\text { 2) } \mathrm{EN} \text { via nasogastric or nasoduodenal routes, Ensure Plus or TraumaCal }(\mathrm{n}=28)\end{array}$} \\
\hline Outcomes & \multicolumn{2}{|c|}{$\begin{array}{l}\text { Death } \\
\text { Disability (using GCS score) } \\
\text { Infection }\end{array}$} \\
\hline Notes & \multicolumn{2}{|c|}{$\begin{array}{l}\text { Fifty-eight patients were originally enrolled into the study. Patients who were brain dead within } 4 \text { days of } \\
\text { entering the study or whose families decided to withdraw them from the study within } 5 \text { days of enrolmen } \\
\text { were excluded from analysis. Seven patients were excluded for the above reasons, leaving } 51 \text { patients for } \\
\text { analysis. Of those, } 5 \text { were brain dead within } 4 \text { days ( } 4 \mathrm{TPN} \text { group, } 1 \text { EN group). } \\
\text { Length of follow-up was for } 1 \text { year post injury. The neurosurgeon who determined outcome was blinded } \\
\text { to the patient's group. } \\
\text { In the final report of } 96 \text { patients deaths were not reported, so for this review the report on } 58 \text { patients was } \\
\text { used }\end{array}$} \\
\hline \multicolumn{3}{|l|}{ Risk of bias } \\
\hline Item & Authors' judgement & Description \\
\hline Allocation concealment? & Unclear & B - Unclear \\
\hline
\end{tabular}

$\mathrm{EN}=$ Enteral nutrition

GCS = Glasgow coma scale

GOS = Glasgow outcome score

LHS = Length of hospital stay

LCT $=$ Long chain triglyceride emulsions

MCT $=$ Medium chain triglyceride

MREE $=$ Measure of resting energy expenditure

$\mathrm{TPN}=$ Total parenteral nutrition

Characteristics of excluded studies [ordered by study ID]

\begin{tabular}{ll}
\hline Study & Reason for exclusion \\
\hline Hausmann 1985 & $\begin{array}{l}\text { The trial looked at a combined enteral/parenteral regimen compared to total parenteral nutrition. The combined } \\
\text { regimen did not state what percentage of calories was provided by which method. It did appear however that } \\
\text { over 50\% was provided by TPN which according to the reviews inclusion criteria would have classified it as TPN } \\
\text { thereby making the comparison TPN versus TPN }\end{array}$ \\
\hline
\end{tabular}


DATA AND ANALYSES

Comparison 1. Timing of intervention: early versus delayed

\begin{tabular}{lcccc} 
Outcome or subgroup title & $\begin{array}{c}\text { No. of } \\
\text { studies }\end{array}$ & $\begin{array}{c}\text { No. of } \\
\text { participants }\end{array}$ & Statistical method & Effect size \\
\hline $\begin{array}{l}\text { 1 Mortality at the end of follow-up } \\
2 \text { Poor outcome at the end of }\end{array}$ & 7 & 284 & Risk Ratio (M-H, Fixed, 95\% CI) & $0.67[0.41,1.07]$ \\
$\quad$ follow-up & 165 & Risk Ratio (M-H, Fixed, 95\% CI) & $0.75[0.50,1.11]$ \\
$\begin{array}{l}3 \text { Length of hospital stay } \\
\text { 4 Infections }\end{array}$ & & & $\begin{array}{l}\text { Other data } \\
\text { Other data }\end{array}$ & No numeric data \\
\hline
\end{tabular}

Comparison 2. Route of intervention: parenteral versus enteral

\begin{tabular}{|c|c|c|c|c|}
\hline Outcome or subgroup title & $\begin{array}{l}\text { No. of } \\
\text { studies }\end{array}$ & $\begin{array}{c}\text { No. of } \\
\text { participants }\end{array}$ & Statistical method & Effect size \\
\hline 1 Mortality at the end of follow-up & 5 & 207 & Risk Ratio (M-H, Fixed, 95\% CI) & $0.66[0.41,1.07]$ \\
\hline $\begin{array}{l}2 \text { Poor outcome at the end of } \\
\text { follow-up }\end{array}$ & 2 & 83 & Risk Ratio (M-H, Fixed, 95\% CI) & $0.69[0.40,1.19]$ \\
\hline 3 Length of hospital stay & & & Other data & No numeric data \\
\hline 4 Infections & & & Other data & No numeric data \\
\hline
\end{tabular}

Comparison 3. Enteral nutrition: jejunal versus gastric

\begin{tabular}{lccll} 
Outcome or subgroup title & $\begin{array}{c}\text { No. of } \\
\text { studies }\end{array}$ & $\begin{array}{c}\text { No. of } \\
\text { participants }\end{array}$ & Statistical method & Effect size \\
\hline $\begin{array}{l}1 \text { Mortality at the end of follow-up } \\
2 \text { Infections }\end{array}$ & 1 & 32 & $\begin{array}{l}\text { Risk Ratio (M-H, Fixed, 95\% CI) } \\
\text { Other data }\end{array}$ & $\begin{array}{l}\text { Not estimable } \\
\text { No numeric data }\end{array}$ \\
\hline
\end{tabular}


Analysis I.I. Comparison I Timing of intervention: early versus delayed, Outcome I Mortality at the end of follow-up.

Review: Nutritional support for head-injured patients

Comparison: I Timing of intervention: early versus delayed

Outcome: I Mortality at the end of follow-up

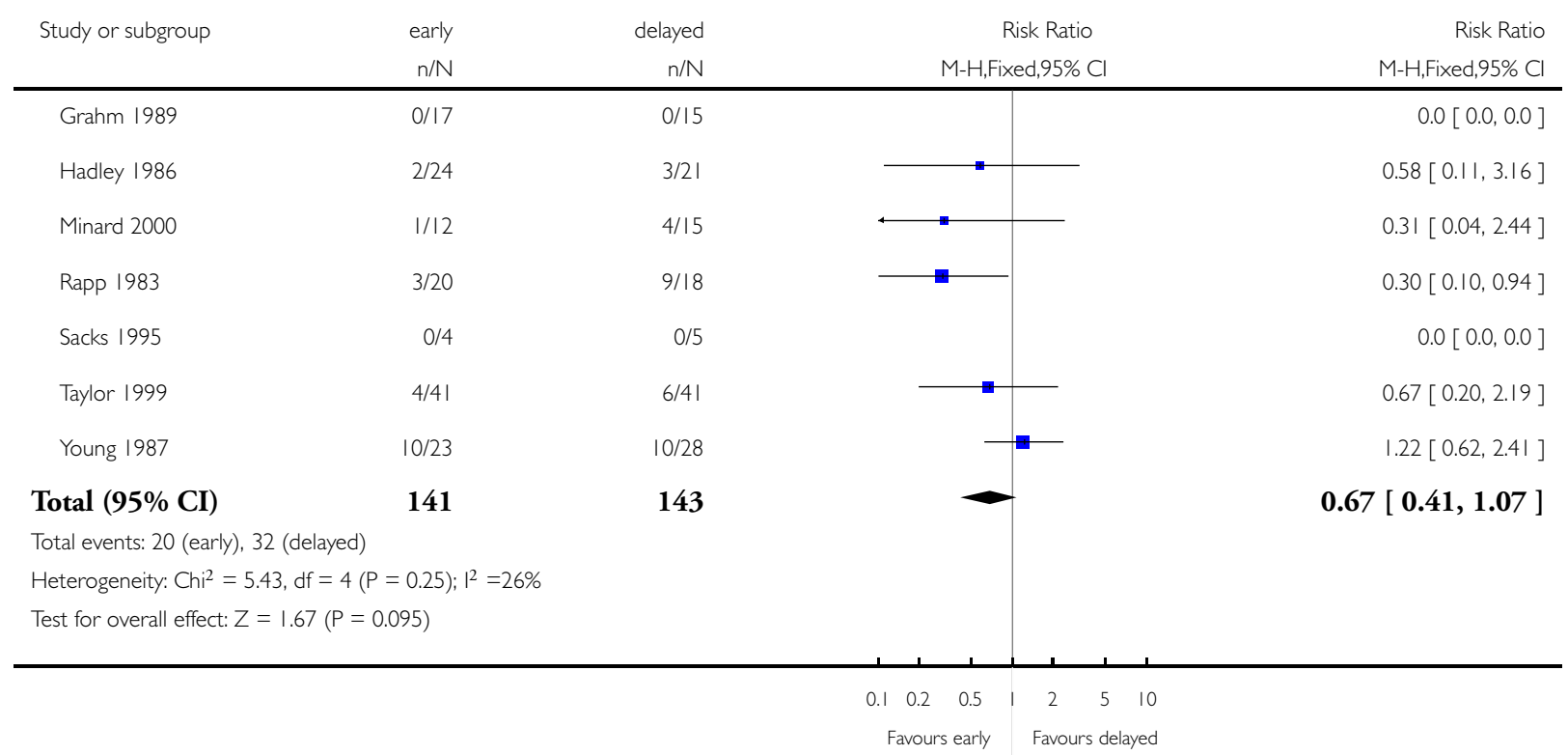


Analysis I.2. Comparison I Timing of intervention: early versus delayed, Outcome 2 Poor outcome at the end of follow-up.

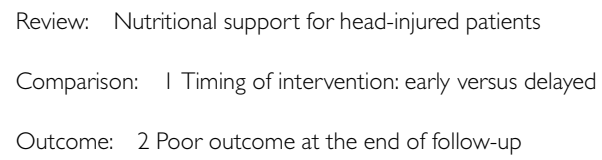

\begin{tabular}{|c|c|c|c|c|c|}
\hline \multirow[t]{2}{*}{ Study or subgroup } & early & delayed & Risk Ratio & Weight & Risk Ratio \\
\hline & $\mathrm{n} / \mathrm{N}$ & $\mathrm{n} / \mathrm{N}$ & M-H,Fixed,95\% Cl & & M-H,Fixed,95\% Cl \\
\hline Hadley 1986 & $7 / 24$ & $7 / 21$ & $\longrightarrow$ & $21.3 \%$ & $0.88[0.37,2.09]$ \\
\hline Rapp 1983 & $7 / 20$ & $11 / 18$ & + & $33.0 \%$ & $0.57[0.28,1.16]$ \\
\hline Taylor 1999 & $|3 / 4|$ & $|6 / 4|$ & 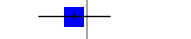 & $45.7 \%$ & $0.81[0.45,1.47]$ \\
\hline
\end{tabular}

Total $(95 \% \mathrm{CI})$

85

80

$100.0 \%$

Total events: 27 (early), 34 (delayed)

Heterogeneity: $\mathrm{Chi}^{2}=0.76, \mathrm{df}=2(\mathrm{P}=0.69) ; 1^{2}=0.0 \%$

Test for overall effect: $Z=1.43(P=0.15)$

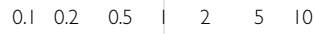

Favours early Favours delayed

Analysis I.3. Comparison I Timing of intervention: early versus delayed, Outcome 3 Length of hospital stay. Length of hospital stay

Study

Grahm 1989 The median length of ICU stay was 7 days (range 4 to 19 days) for the early group and 10 days for the control group

Minard 2000 The average length of ICU stay was 18.5 in the early group and 11.3 in the late group. when deaths were excluded the average length of stay was 19.3 in the early group and 11.7 in the late group

Taylor 1999 The early enhanced enteral nutrition group achieved discharge more quickly (median days to discharge 30 versus 46 for the control group)

Analysis I.4. Comparison I Timing of intervention: early versus delayed, Outcome 4 Infections.

Infections

Study

Grahm 1989 In the early jejunal EN group $(\mathrm{n}=17) 3$ patients had an infection of some sort (2 had pneumonia and 1 had bronchitis) . In the delayed EN group $(n=15)$ there was a total of 14 infections in 10 patients reported (3 pneumonia, 10 bronchitis, 1 ventriculitis)

Hadley 1986 In the TPN group $(n=24)$ there was a total of 17 bacterial infections. In the NG group $(n=21)$ there was a total of 15 bacterial infections. These infections occured in 25 patients however it is not reported how many of those patients were in each group. Only the total number of infections for each group is reported 
Infections (Continued)

Minard 2000 In the early nutrition group 6 patients developed pneumonia and in the late group 7 patients developed pneumonia

Sacks 1995 In the early TPN group $(\mathrm{n}=4) 3$ patients developed an infection. In the delayed TPN group $(\mathrm{n}=5)$ four patients developed an infection. This information was obtained on contact with the author

Taylor 1999 One patient in each group suffered aspiration pneumonia (confirmed by tracheal aspiration of feed). Pneumonia from all causes occured in $63 \%$ of the delayed group and $44 \%$ of the early group

Young 1987 The incidence of infections was recorded as percentages. In the TPN group ( $\mathrm{n}=23$ ), no patients had sepsis, $26.1 \%$ got a urinary tract infection, and $26.1 \%$ had pneumonia. In the EN group $(n=28) 10.7 \%$ had sepsis, $25 \%$ had a urinary tract infection and $32.1 \%$ had pneumonia. Septicemia was defined by fever, increased WBC count, and positive blood cultures

Analysis 2.I. Comparison 2 Route of intervention: parenteral versus enteral, Outcome I Mortality at the end of follow-up.

Review: Nutritional support for head-injured patients

Comparison: 2 Route of intervention: parenteral versus enteral

Outcome: I Mortality at the end of follow-up

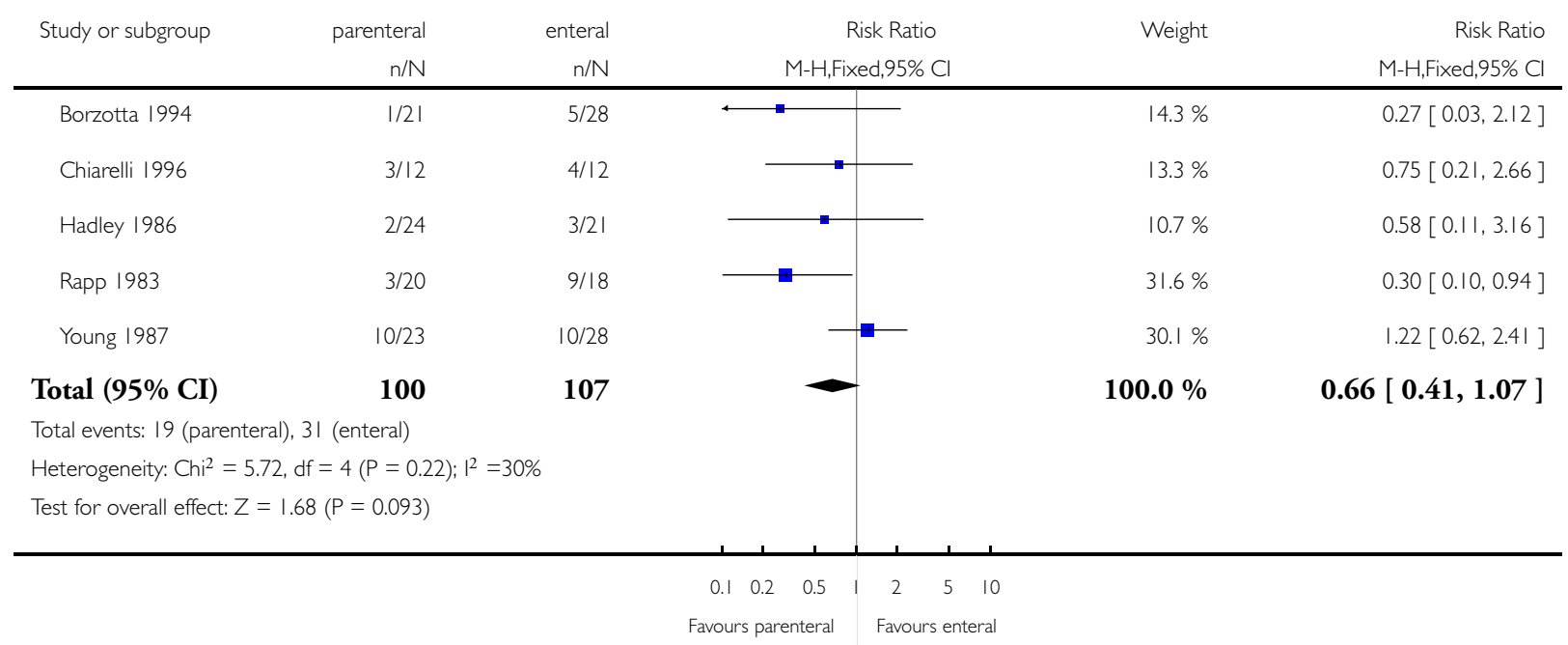




\section{Analysis 2.2. Comparison 2 Route of intervention: parenteral versus enteral, Outcome 2 Poor outcome at the end of follow-up.}

Review: Nutritional support for head-injured patients

Comparison: 2 Route of intervention: parenteral versus enteral

Outcome: 2 Poor outcome at the end of follow-up

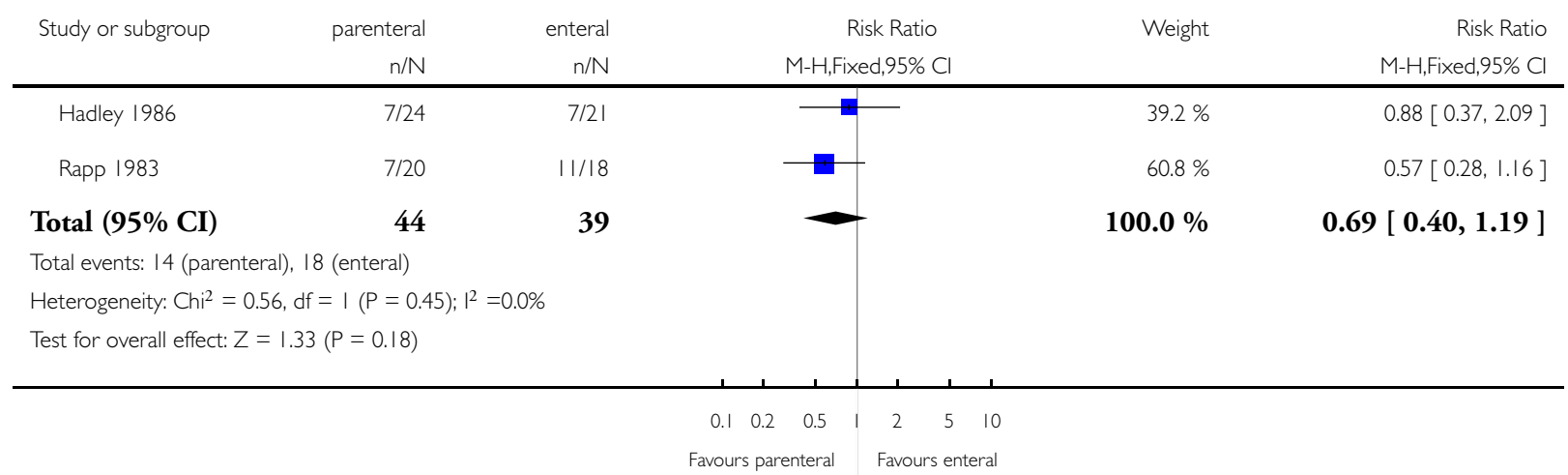

Analysis 2.3. Comparison 2 Route of intervention: parenteral versus enteral, Outcome 3 Length of hospital stay.

Length of hospital stay

Study

Borzotta 1994 In the TPN group the mean length of hospital stay in days was 39.9 (SD 14) and in the EN group the mean length of stay in days was 39.1 (SD23.1)

Chiarelli 1996 The median number of days for hospital stay was given. For the EN group the number was 41 (SD 23) and for the mixed nutrition group the median number of days was 37 (SD 13)

Analysis 2.4. Comparison 2 Route of intervention: parenteral versus enteral, Outcome 4 Infections. Infections

Study

Borzotta 1994 In the TPN group $(n=21)$ there was a total of 39 infections (sinusitis 6, bronchitis 6, pneumonia 9, peritonitis 1, wound infection 1 , clostridium difficile 4, UTI 6 , intravascular device 2, bacteremia 4). This was a total of 1.86 infections per patient.

In the ENT group ( $\mathrm{n}=28$ ), there was a total of 51 infections (meningitis 2, sinusitis 3, bronchitis 6, pneumonia 15, wound infection 6 , clostridium difficile 2 , UTI 6 , intravascular device 3 , bacteremia 8 ). This was a total of 1.89 infections per patient

Chiarelli 1996 In the group weaned to TEN $(n=12)$ there were 6 cases of bronchoaspiration and in the group weaned to a mixture of TEN and TPN there were 7 cases of bronchoaspiration 
Hadley 1986 In the TPN group ( $\mathrm{n}=24)$ there was a total of 17 infections (9 pneumonia, 3 sepsis, 1 wound infection, 2 meningitis and 2 urinary tract). In the NG group $(n=21)$ there was a total of 15 infections ( 10 pneumonia, 1 sepsis, 2 wound infections, 1 meningitis and 1 urinary tract). These infections occured in 25 patients; however it is not reported how many of those patients were in each group. Only the total number of infections for each group is reported. NB these are the same data that are in the early vs late comparison

Young 1987 The incidence of infections was recorded as percentages. In the TPN group ( $\mathrm{n}=23$ ), no patients had sepsis, $26.1 \%$ got a urinary tract infection, and $26.1 \%$ had pneumonia. In the EN group ( $\mathrm{n}=28) 10.7 \%$ had sepsis, $25 \%$ had a urinary tract infection and $32.1 \%$ had pneumonia.

NB these are the same data that are in the early vs late comparison

\section{Analysis 3.I. Comparison 3 Enteral nutrition: jejunal versus gastric, Outcome I Mortality at the end of follow-up.}

Review: Nutritional support for head-injured patients

Comparison: 3 Enteral nutrition: jejunal versus gastric

Outcome: I Mortality at the end of follow-up

\begin{tabular}{|c|c|c|c|c|}
\hline \multirow[t]{2}{*}{ Study or subgroup } & \multirow{2}{*}{$\begin{array}{r}\text { Treatment } \\
\mathrm{n} / \mathrm{N}\end{array}$} & \multirow{2}{*}{$\begin{array}{r}\text { Control } \\
\mathrm{n} / \mathrm{N}\end{array}$} & \multirow{2}{*}{$\begin{array}{c}\text { Risk Ratio } \\
\text { M-H,Fixed,95\% Cl }\end{array}$} & \multirow{2}{*}{$\begin{array}{r}\text { Risk Ratio } \\
\text { M-H,Fixed,95\% Cl }\end{array}$} \\
\hline & & & & \\
\hline Grahm 1989 & $0 / 17$ & $0 / 15$ & & $0.0[0.0,0.0]$ \\
\hline Total (95\% CI) & 17 & 15 & & $0.0[0.0,0.0]$ \\
\hline \multicolumn{5}{|c|}{ Total events: 0 (Treatment), 0 (Control) } \\
\hline \multicolumn{5}{|c|}{ Heterogeneity: not applicable } \\
\hline Test for overall effect & $0001)$ & & & \\
\hline
\end{tabular}

$\begin{array}{lllllll}0.1 & 0.2 & 0.5 & 1 & 2 & 5 & 10\end{array}$

Favours Treatment Favours Control 


\section{A P P E N D I C E S}

\section{Appendix I. Search strategy}

The searches were based on the following MEDLINE search strategy, adapted as appropriate to the specifications of each database; MEDLINE

1. exp CRANIOCEREBRAL TRAUMA/

2. $\exp$ BRAIN EDEMA/

3. $\exp$ GLASGOW COMA SCALE/

4. exp GLASGOW OUTCOME SCALE/

5. exp UNCONSCIOUSNESS/

6. Diffuse axonal injur\$.ab,ti.

7. Rancho Los Amigos Scale.ab,ti.

8. ( (head or crani\$ or cerebr\$ or capitis or brain $\$$ or forebrain $\$$ or skull $\$$ or hemispher $\$$ or intra-cran $\$$ or inter-cran $\$$ ) adj3 (injur $\$$ or trauma $\$$ or lesion $\$$ or damag $\$$ or wound $\$$ or destruction $\$$ or oedema $\$$ or edema $\$$ or fracture $\$$ or contusion $\$$ or concus $\$$ or commotion $\$$ or pressur\$)).ab,ti.

9. 1 or 2 or 3 or 4 or 5 or 6 or 7 or 8

10. exp Enteral Nutrition/

11. exp Parenteral Nutrition/

12. (enteral adj3 (feed $\$$ or nutrition $\$)$ ).ab,ti.

13. (parenteral adj3 (feed\$ or nutrition\$)).ab,ti.

14. nutritional support.ab,ti.

15. 10 or 11 or 12 or 13 or 14

16. 9 and 15

17. clinical trial.pt.

18. randomized.ti,ab.

19. placebo.ti,ab.

20. drug therapy.fs.

21. randomly.ti,ab.

22. trial.ti,ab.

23. groups.ti,ab.

24.17 or 18 or 19 or 20 or 21 or 22 or 23

25. exp animals/

26. exp humans/

27. 25 not (25 and 26)

28. 24 not 27

29. 16 and 28

The RCT search filter used was developed by (Glanville 2006).

\section{WHAT'S NEW}

Last assessed as up-to-date: 1 August 2006.

\begin{tabular}{lll}
\hline Date & Event & Description \\
\hline 11 July 2008 & Amended & Converted to new review format. \\
\hline
\end{tabular}




\section{H I S T O R Y}

Protocol first published: Issue 2, 1999

Review first published: Issue 2, 2000

\begin{tabular}{l|l|l}
\hline Date & Event & Description \\
\hline 2 August 2006 & New search has been performed & $\begin{array}{l}\text { July 2006 } \\
\text { The searches were updated in July 2006; no new trials for inclusion were ideni- } \\
\text { tified. } \\
\text { Pablo Perel has taken over as contact author. }\end{array}$ \\
\hline
\end{tabular}

\section{CONTRIBUTIONS OFAUTHORS}

PP updated the review and has taken over as contact author. TY designed the protocol, screened citations for eligibility, extracted data, entered data into RevMan and helped to write the original review. FB screened citations for eligibility, extracted data, contacted authors and helped to write the original review. IR helped to design the protocol and write the review. RW designed and ran the searches. AP commented on the protocol and the review.

\section{DECLARATIONS OF INTEREST}

None known.

\section{SOURCES OF SUPPORT}

\section{Internal sources}

- Japanese Imperial Foundation : Boshi-Aiikukai, Japan.

\section{External sources}

- No sources of support supplied

\section{N D X TERMS}

\section{Medical Subject Headings (MeSH)}

${ }^{*}$ Craniocerebral Trauma [mortality; therapy]; *Nutritional Support; Enteral Nutrition; Parenteral Nutrition; Randomized Controlled Trials as Topic; Time Factors; Treatment Outcome 


\section{MeSH check words}

Humans

Copyright (@ 2008 The Cochrane Collaboration. Published by John Wiley \& Sons, Ltd. 